IJMS 17 (2), 143-164 (2010)

\title{
YOUNG ADULTS' SUSCEPTIBILITY TO INTERPERSONAL INFLUENCE: A CASE OF APPAREL PURCHASES
}

\author{
WENG MARC LIM \\ DING HOOI TING \\ School of Business \\ Monash University
}

\begin{abstract}
Purpose: This paper focuses on consumers' susceptibility to interpersonal influence of young adults in the clothing apparels' market in Malaysia. The researchers sought to clarify the relationship between interpersonal influences and young adults' purchase decision, and the moderating impact of gender towards the relationship.
\end{abstract}

Design/methodology/approach: This study is exploratory in nature and adopts a quantitative approach. Primary data were obtained from young adults in Klang Valley (Malaysia) using mall intercept, by using 300 questionnaires were administrated using a multi-stage probability sampling technique to young adults between 19 to 30 years old.

Findings: Findings showed that value expressive, utilitarian, information, and brand consciousness influences were positively related to purchase decision. There are differences between genders toward the strength of interpersonal influence resulting in variation in their purchase decision.

Research limitations/implications: Different strategies should be designed to cater to both informational and brand consciousness influences between genders.

Originality/value: Marketers will be able to understand the importance of identifying the different susceptibility factors and gender attribute in their attempt to design different marketing strategies to attract customers.

Keywords: Interpersonal influence; value expressive; utilitarian; information; brand consciousness. 


\begin{abstract}
Abstrak
Tujuan: Kajian ini berfokuskan pada kerentanan pelanggan terhadap pengaruh interpersonal dalam kalangan golongan dewasa muda dalam pasaran pakaian di Malaysia. Di dalam kajian ini, penyelidik berusaha untuk menjelaskan hubungan antara pengaruh interpersonal dan keputusan pembelian golongan dewasa muda serta pengaruh jantina sebagai angkubah penyederhana dalam hubungan ini.
\end{abstract}

Design/Metodologi/Pendekatan: Kajian ini merupakan satu penyelidikan eksplorasi dan menggunakan pendekatan kuantitatif. Data primer diperoleh daripada orang dewasa muda di Lembah Klang (Malaysia) dengan menggunakan kaedah 'intercep pasaran'. Borang soal selidik sebanyak 300 telah diagihkan kepada orang dewasa muda di antara umur 19 hingga 30 tahun menggunakan kaedah kebarangkalian 'persampelan pelbagai-tahap'.

Dapatan Kajian: Dapatan kajian menujukkan nilai ekspresif, utilitarian, maklumat, dan pengaruh kesedaran jenama mempunyai kaitan positif dengan keputusan pembelian. Selain itu, penyelidikan ini juga mendapati bahawa terdapat beberapa perbezaan di antara jantina terhadap kekuatan pengaruh interpersonal yang mengakibatkan variasi di dalam keputusan pembelian mereka.

Batasan Kajian/Implikasi: Strategi yang berbeza perlu direka untuk memenuhi keperluan maklumat dan pengaruh kesedaran jenama di antara jantina.

Keaslian/Nilai: Golongan pemasar akan memperoleh pemahaman yang lebih mendalam tentang kepentingan untuk mengenal pasti faktor-faktor kerentanan yang berbeza dan pengaruh jantina dalam usaha mereka untuk merancang strategi pemasaran yang berbeza untuk menarik pelanggan.

Kata Kunci: Pengaruh interpersonal; nilai ekspresif; utilitarian; maklumat; kesedaran jenama.

\title{
Introduction
}

In the global modern economy, young adults are seen as a lucrative market in its own right (Spero \& Stone, 2004). According to Spero and Stone (2004), this group of consumers were found to be a powerful consumer spending group and they were identified of possessing buying power of more than $\$ 200$ billion each year. In DSN

144 IJMS 17 (2), 143-164 (2010) 
Retailing Today (2004), it was found that year-to-year, young adults' expenditures in clothing apparels are increasing at a fast rate. This was confirmed by Xu (2008) whereby it was stated that young adults were found to spend their earnings as quickly as they acquire it, usually on consumer goods such as clothing. According to Euromonitor (2009), the apparel industry in the Asia-Pacific region is an increasingly competitive market with a market size of approximately USD330 million in 2008 (Euromonitor, 2009). Michaelidou and Dibb (2009) stipulated that the clothing sector is considered to be an important sector contributing to the rise in a country's economic growth as it is attracting considerable marketing spending.

Clothing, and fashionable clothing in particular, is a publicly consumed good that signals the information about the status and personality of the wearer to other people (Dodd, Clarke, Baron \& Houston, 2000). The consumption of this good is often affected by consumers' preferences for clothing apparels. Their preferences often differ as consumers may seek the opinions of others to evaluate their choice decisions. In turn, this may lead them to making decisions differing to the ones they would have made in the absence of real or imagined public assessment (Bearden, Netemeyer \& Teal, 1989; Ratner \& Khan, 2002). In their well-known work, Ratner and Khan (2002) found that consumers often conform to group norms as they desire to create a favourable impression on others. In addition, Ariely and Levav (2000) found that consumers' tend to modify their judgements in order to be accepted into a group. In their study, it was concluded that in the presence of others, consumers tend to balance their individual goals with collective goals leading to a reduction in personal satisfaction. In yet another study, Bearden et al. (1989) found that one would generally purchase based on what others would think about one's purchase. This is further justified in Dahl, Manchanda, and Argo's (2001) research as consumers were found to avoid embarrassment by purchasing based on what others approved of. Although susceptibility to interpersonal influence is regarded as a significant individual difference variable for the study of consumer behaviour, unfortunately, this general trait is very much seen as an infertile area of research in the recent marketing studies. Typically, the study of interpersonal susceptibility to purchase decisions in the Malaysian context is a shadowed area which has been overlooked by most researchers. They tended to focus more toward areas in sales promotions to generate immediate sales as compared to generating demand by taking advantage of its target market's susceptibility to interpersonal influence. Subsequently, the opportunity to increase 
market share and profits has been limited as a result of a blind-spot understanding in this area of research. Understanding the role of interpersonal factors in consumers' purchase decision is essential to organisations as these factors would play an influential role in determining what the consumers' will be purchasing. Hence, the motivation of this study was to determine the factors that influences young adults' purchase decision, as well as the role of gender in influencing the relationship between interpersonal influences and purchase decision.

In turn, the theoretical by-product of the study is a clearer understanding of how the interpersonal factors influence the consumers' purchase decision. Notably, the body of knowledge will be enhanced with a better understanding of consumer behaviour from the Malaysian context. Results of essential information would enhance the marketers' knowledge on consumer behaviour - susceptibility to interpersonal influence, and becomes a base of required information for organisations in developing successful marketing mix strategies. Typically, organisations would be able to refrain from experiencing unwanted circumstances and utilise the understanding of interpersonal susceptibility of the population under study in successfully marketing its offerings to its target market.

\section{Review of Past Research}

Various studies and research have come to a conclusion that the influence of others, or interpersonal influence, is an essential determinant of an individual's behaviour (Abrams, 1994; Lascu, Bearden \& Rose, 1995; Terry \& Hogg, 1996). In those studies, interpersonal influence is seen as an important facet in shaping consumer behaviour, particularly in the purchase decision. According to Keaveney (1995), consumers will identify and choose alternatives of a product with reference to others before making a final choice of purchase. Indirectly, the act of referring to others in their purchase decision brings about a direction of vulnerability (Burnkrant \& Cousineau, 1975).

Previous researchers have been looking at how the value expressive influence impacts upon consumers. In the recent studies on value expressiveness, it has been suggested that individuals are rather vulnerable toward this influence (Bearden et al., 1989; Keaveney, 1995; Kelman, 1961). According to Burnkrant and Cousineau (1975), there is evidence that suggests that individuals have the desire to enhance their self-image. Keaveney (1995) found that these individuals often 
do so by associating themselves with a particular reference group. This has been confirmed by Kelman (1961) who stated that individuals have a desire to enhance or support their self-concept through referent identification. Bearden et al. (1989), and Brinberg and Plimpton (1986) suggested that this process of identification often transpires in the event where an individual adopts a behaviour or opinion of another with regard to its association with satisfying a self-defining relationship. In a more recent study by Kellery and Kalmus (2009), these individuals were found to increasingly associate themselves with reference groups in which they believe are able to enhance their overall image to look cool. Consequently, these individuals would make purchase decisions which are similar to those of the reference group (Bearden \& Etzel, 1982). Many retailers in Malaysia confirmed the above findings as they noticed young Malaysians tend to express their self-concept by following styles of those groups in the current trend which in turn reflects on their purchases of products used in those reference groups (Lee and Lim, personal communications, January 19, 2010). In turn, the tendency to the above provides an opportunity for value expressive influence. The above discussions lead to the formulation of the first hypothesis under study:

H1: Value expressive has a positive impact toward young adults' purchase decision.

Utilitarian influence is a complex construct and has been generally defined as the pressure to comply with the expectations of others (Bearden \& Etzel, 1982; Burnkrant \& Cousineau, 1975; Park \& Lessig, 1977). In the well-known work of Dahl et al. (2001), it was suggested that consumers' purchase decision of a particular product is often based on the acceptance of others. Netemeyer, Bearden, and Teel (1992) also found that consumers with this kind of behaviour are often obedient in their purchases in relation to the expectations required of them by their peers. The power of others in mediating the situation with rewards or punishments further adds toward this compliance (Park \& Lessig, 1977; Burnkrant \& Cousineau, 1975). In addition, a recent study by Goldsmith and Clark (2008) presented an upward trend in approval seeking of others with regard to fashion. According to Liung, it was found that Malaysians had the tendency to purchase products which grants them acceptance and increase their favourability with their peers (personal communication, January 18, 2010). From the response obtained, the purchase of those offerings will put them in a position of respect amongst their peers. Subsequently, consumers would comply with what is approved by others in order to make a good impression and thus based their purchase decision on 
the approved behaviour (Bertrandias \& Goldsmith, 2006). The second hypothesis of the study was based on the utilitarian perception that influences purchase decision.

H2: Utilitarian influence is capable of impacting young adults' purchase decision positively.

Many researchers have come to a conclusion that individuals tend to search for information regarding a particular something that they are not so familiar with (Barber, Dodd \& Kolyesnikova, 2009; Bearden et al., 1989; Brown \& Reingen, 1987; Gronhoj, 2007; Schroeder, 1996). The outcomes of Schroeder's (1996) and Barber et al. (2009) research showed that individuals seek the help of knowledgeable others to fulfil their informational needs. A study carried out by Bearden et al. (1989), implied that individuals have the tendency to accept information from others as evidence about reality which in turn influences their purchase decision. There is evidence which suggests that seeking information from friends and accepting advice from parents can help reduce the costs of informational search when making their decision on what would be the best purchase (Brown \& Reingen, 1987). This has been confirmed by Gronhoj (2007) who conclusively stated that these cost savings have encouraged young adults to seek for the desired information from others before making a purchase. Meanwhile, the study by Burnkrant and Cousineau (1975), and Barber et al. (2009) suggested that individuals are highly susceptible indirectly toward informational influence as most individuals are found to have a propensity to observe. An interview with several retailers in Malaysia has validated the above findings as it is confirmed that most Malaysians tend to ask for more information about an offering from others, whether it is a friend or a sales person, and make observations of those using the products before making their purchase decision (Lee and Lim, personal communications, January 19, 2010). In turn, these observations become an influential consideration to the individual's purchase. This made consumers rather vulnerable to the informational influences. Thus, the discussions led to the basis of our third hypothesis.

H3: Young adults are positively susceptible to interpersonal influence in the purchase decision.

In another context, various researchers have suggested that individuals tend to purchase branded products with reference to others (Chan, 2006; Rojsek, 2001; Shim \& Gehrt, 1996). In the studies by Shim and Gehrt (1996), and O'Cass and Frost (2002), it 
was found that individuals tend to be oriented toward buying wellknow branded products influenced by people around them. This is supported by Delong, Bao, Wu, Chao, and Li (2004), whereby their findings stated that young adults tend to purchase branded products that are popular among others. Rojsek (2001), and Phau and Cheong (2009) found that certain individuals do consider brands that they have never tried before in making their purchase decision if they see many people using it. Subsequently, Porter and Claycomb (1997), and Husic and Cicic (2009) found that individuals tend to give more attention to brand names that are mentioned by others. This is supported by Fatha as brands that are exclusive and commonly used are usually favourable considerations when making purchase decisions among Malaysian consumers (personal communication, January 17, 2010). Chan (2006), and Husic and Cicic (2009) claimed that brand recommendations among peers were perceive as a strong consideration in the purchases of young adults. These attention and recommendations becomes influential to what these individuals would purchase which led to the fourth hypothesis.

H4: Brand consciousness influence is able to generate a positive impact on young adults' purchase decision.

Prior researchers have also looked at the differences in gender when it comes to making purchase decisions based on the above interpersonal influence factors. For instance, women are found to process information from various informational influences differently from men (Peter \& Olson, 1996). Livette (2006) and Barber et al. (2009) suggested that this will impact on their purchase decision. Fournier (1998) had concluded that gender variation would imply different strength levels of interpersonal and brand relationships in their purchases. According to Liung, it was found that young Malaysian females had a higher tendency to be influenced by utilitarian influences and brand consciousness influence as compared to young Malaysian men (personal communication, January 18, 2010). This further suggested that young male adults and young female adults would have different strengths in applying the effect of brand consciousness when making their purchase decisions (Coley \& Burgess, 2003). Ultimately, the study of Wood (1998), and Hansen and Jensen (2009) found that demographic characteristics (gender) of customers would affect how they would make their purchase decisions. Based on the above discussion, the following hypothesis were developed.

H5: There are differences between gender in terms of interpersonal influence and purchase decision. 


\section{Methodology}

The data required for the analysis were acquired through the distribution of questionnaires using the face-to-face method - mall intercept type, as it provides a higher and easier chance of asking young adult shoppers directly. The researchers employed a multi-stage probability sampling technique consisting of three stages - simple random sampling, stratified sampling, and systematic sampling, to ensure randomisation of all sampling units to minimise and eliminate biasness. A total of 300 questionnaires were administrated to the young adults at Klang Valley - those aged between 19 to 30 years old in shopping malls during random shopping hours to gain a randomised set of respondents. Shopping malls in the Klang Valley was chosen as the central of study since many main activities are focused around Klang Valley and people from different states flocked to Klang Valley in search of jobs, education, entertainment, and etc.

\section{Respondents Background}

Table 1 illustrates the respondents' background of this study.

Table 1

Background of Respondents

\begin{tabular}{llcc}
\hline & & Frequency & Percentage (\%) \\
\hline \multirow{2}{*}{ Gender } & Male & 150 & 50.0 \\
& Female & 150 & 50.0 \\
\hline \multirow{2}{*}{ Race } & Malay & 141 & 47.0 \\
& Chinese & 109 & 36.3 \\
& Indian & 44 & 14.7 \\
& Others & 6 & 2.0 \\
\hline \multirow{2}{*}{ Marital Status } & Single & 142 & 47.3 \\
& Married & 148 & 49.3 \\
& Divorce & 10 & 3.3 \\
\hline & & & (continued)
\end{tabular}




\begin{tabular}{llcc}
\hline & & Frequency & Percentage (\%) \\
\hline \multirow{2}{*}{ Age } & $19-22$ & 107 & 35.7 \\
& $23-26$ & 73 & 24.3 \\
& $27-30$ & 120 & 40.0 \\
\hline \multirow{2}{*}{ Income (per month) } & RM0-RM2000 & 86 & 28.7 \\
& RM2001-RM4000 & 71 & 23.7 \\
& RM4001-RM6000 & 97 & 32.3 \\
& RM6001 and above & 46 & 15.3 \\
\hline & Total & 300 & 100.0 \\
\hline
\end{tabular}

Note. US $\$ 1.00=$ RM3.498 (as of 1 November, 2009)

The respondents of this study were equally distributed $-50 \%$ each for young male adults and young female adults. Most of the respondents are Malays (47\%) followed by Chinese (36.3\%), Indians (14.7\%), and others $(2 \%)$.

Some $49.3 \%$ of the respondents were already married, while $47.3 \%$ of them were still single. Only 10 respondents were divorced. This corresponds to their age groups as majority of the respondents were 27 to 30 years of age $(40 \%)$ and are more likely to be in a married relationship. In contrast, $35.7 \%$ of the respondents were 19 to 22 years of age whereas $24.3 \%$ were 23 to 26 years of age. Hence, this mirrors the $47.3 \%$ of respondents who were still single.

Most of the respondents had income from the range of RM4001 to RM6000 (32.3\%). About 28.7\% of the respondents had earnings of RM0 to RM2000, whereas another $23.7 \%$ were in the range of income - RM2001 to RM4000. Only 15.3\% of the respondents had an income of RM6001 or more.

\section{Factor Analysis and Reliability}

In order to group items in the questionnaire into a homogenous factor, the researchers had factor analysed these items, where eight items fell into the value expressive influence dimension, seven items fell into the utilitarian influence dimension, five items fell in the 
informational influence dimension, and another five items fell in the brand consciousness influence dimension (refer to the Appendix). There were no signs of cross-loadings in all dimensions.

Table 2

Cronbach Alpha Reliability

\begin{tabular}{lc}
\hline Variables & Cronbach Alpha \\
\hline Value Expressive (1) & .914 \\
Utilitarian (2) & .909 \\
Informational (3) & .866 \\
Brand Consciousness (4) & .855 \\
Purchase Decision (5) & .884 \\
\hline
\end{tabular}

Table 2 above shows that the measurements used have internal consistency. Eigenvalue of greater than 1 is used in order to group the items into certain factors that are able to reflect the dimensions. All Cronbach alpha values were above the .80 level and are deemed to have very reliable measurements for the respective dimensions.

\section{Regression}

The following regression model was utilised to examine the relationship between the four independent variables and purchase decision. Simple regression analysis was used to determine the significance level of the relationship, where $p<.01$ was employed. The model under study was as follows:

$Y=\alpha_{1}+\alpha_{2} X_{1}+\alpha_{3} X_{2}+\alpha_{4} X_{3}+\varepsilon$

where

$Y=$ purchase decision,

$X_{1}=$ value expressive influence,

$X_{2}=$ utilitarian influence,

$X_{3}=$ informational influence,

$X_{4}=$ brand consciousness influence, and

$\varepsilon=$ error term.

Using the regression analysis, Table 3 depicts the results obtained.

152 IJMS 17 (2), 143-164 (2010) 
Table 3

Empirical Regression of Interpersonal Influence and Purchase Decision

\begin{tabular}{lc}
\hline & $B$ \\
\hline Constant & $.422^{* *}$ \\
Value Expressive & $.145^{* *}$ \\
Utilitarian & $.277^{* *}$ \\
Informational & $.240^{* *}$ \\
Brand Consciousness & $.256^{* *}$ \\
$R^{2}$ & $.593^{* *}$ \\
Adjusted $R^{2}$ & $.588^{* *}$ \\
$F$ & $102.534^{* *}$ \\
Sig. F & .000 \\
\hline
\end{tabular}

The $t$-test on the coefficients of all independent variables are significant at $p<.01$ based on the regression analysis of the model above. This means that all independent variables are positively correlated to the dependent variable. By writing the regression model in full, the following was obtained:

$\hat{Y}=.0422^{* *}+.0145 X_{1}^{* *}+.0277 X_{2}^{* *}+.0240 X_{3}^{* *}+.0256 X_{4}^{* *}$

The adjusted $R^{2}$ (which takes into consideration the number of parameters estimated) wa obtained as .588 , while the $R^{2}$ was .593 .

In order to test Hypothesis 5, the following analysis was conducted to examine the differences between demographic variables on interpersonal factors and purchase decision.

Table 4

Tests of Differences Between Genders on Interpersonal Factors

\begin{tabular}{lccc}
\hline Variables & Gender & Mean & Sig. F \\
\hline Purchase Decision & Male & 4.25 & .00 \\
& Female & 4.43 & .79 \\
\hline Value Expressive & Male & 4.34 & .79 \\
& Female & 4.37 & \multirow{2}{*}{.03} \\
\hline Informational & Male & 4.24 & \\
& Female & 4.30 &
\end{tabular}

(continued) 


\begin{tabular}{lccc}
\hline Variables & Gender & Mean & Sig. F \\
\hline Brand Consciousness & Male & 4.22 & \multirow{2}{*}{.00} \\
& Female & 4.34 & \multirow{2}{*}{.19} \\
\hline \multirow{2}{*}{ Utilitarian } & Male & 4.43 & \\
& Female & 4.44 & \\
\hline
\end{tabular}

The results from Table 4 show that there are differences between gender toward their perceptions on purchase decision, informational influence, and brand consciousness $\mathrm{p}<.05$, while no differences exists between gender in terms of value expressiveness and utilitarian.

In order to further understand the strength between gender for the purchase decision, informational influence, and brand consciousness, the following graphical representation was computed.

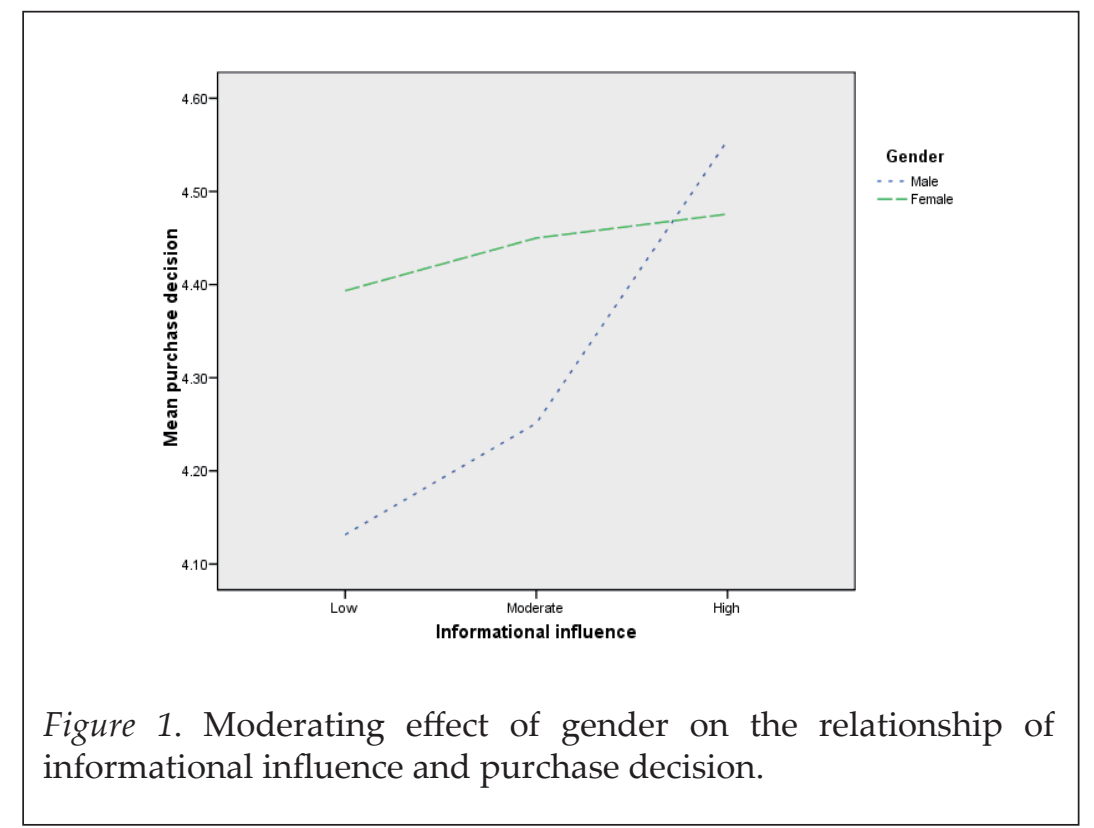

As can be observed from Figure 1, for young male adults, as the strength of informational influence moves from low to moderate, vulnerability to the influence in the purchase decision will increase. However, as the strength of informational influence increases from moderate to high, susceptibility to the influence in the purchase decision is increasing at a growing rate. In contrast, for young female adults, as the strength of informational influence increases from low to moderate, vulnerability to the influence in the purchase decision 
will increase. Nevertheless, as the strength of informational influence moves from moderate to high, susceptibility to the influence in the purchase decision is increasing at a declining rate.

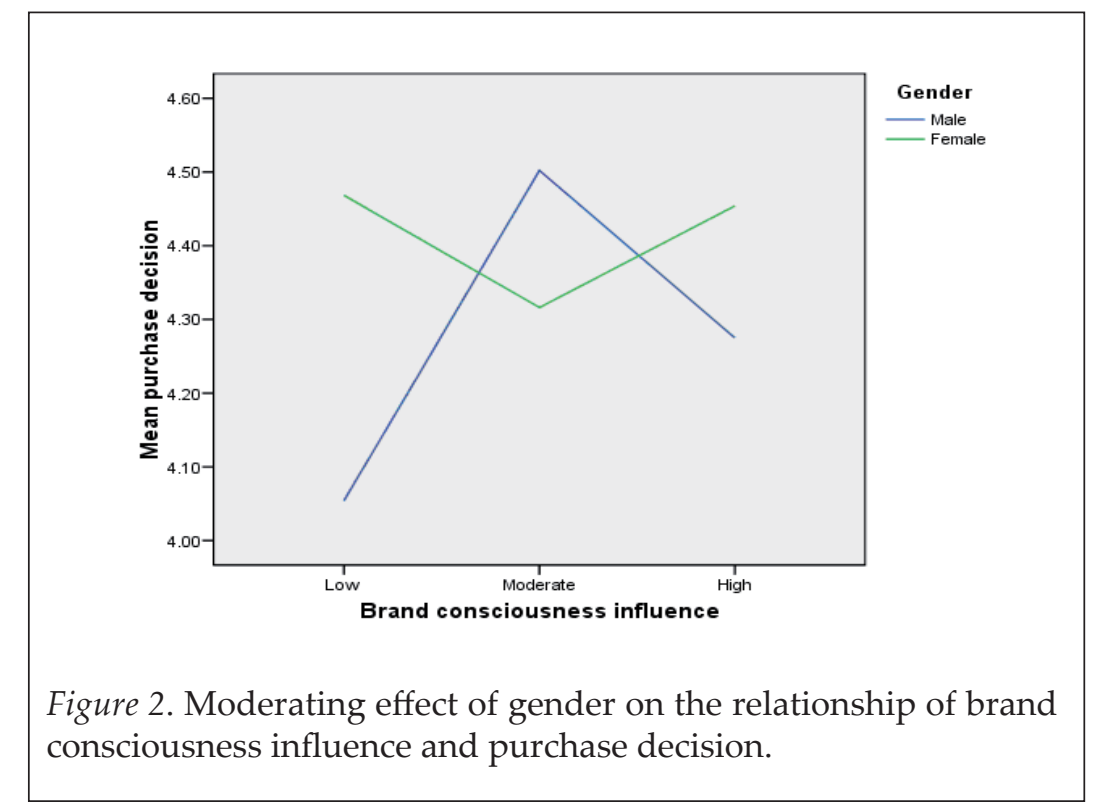

From Figure 2, for young male adults, as the strength of brand consciousness influence moves from low to moderate, vulnerability to the influence in the purchase decision will increase. However, as the strength of brand consciousness influence increases from moderate to high, susceptibility to the influence in the purchase decision begins to decline. In contrast, for young female adults, as the strength of brand consciousness influence increases from low to moderate, vulnerability to the influence in the purchase decision will decline. Nevertheless, as the strength of brand consciousness influence moves from moderate to high, susceptibility to the influence in the purchase decision begins to increase.

\section{Discussion and Managerial Implications}

Young adults' purchase decision making processes are often influenced interpersonally. Subsequently, the present study examined the properties, structure, and mean levels of the susceptibility to interpersonal influence construct across samples of young adults in Klang Valley with regard to the clothing apparels context. 
This study contributes to the body of knowledge in a number of ways. One theoretical by-product of the study is a clearer understanding on how interpersonal factors would influence upon young adults' purchase decision and the authority of gender in this process.

Value expressive, utilitarian, informational, and brand consciousness influences were positively related to the purchase decision of young adults. This implies that the vulnerability of young adults to the above four interpersonal influences becomes a sustainable consideration in the purchase of clothing apparels. In the managerial implications context, value expressiveness, utilitarian, informational, and brand consciousness influences are concluded to impact on the purchase decision making process positively, and thus are deemed as predictors of young adults' susceptibility to interpersonal influence in the mentioned process.

An additional theoretical implication evinced from the study is the moderating relationship of gender between interpersonal influences and purchase decision. This study suggested that there are differences which exist in the strength of interpersonal influence between young male adults and young female adults resulting in a variation in their purchase decision. Conclusively, young female adults experience a stronger application of interpersonal influence when making their purchase decision compared to young male adults.

In addition, marketers should take notice of the difference in the strength of interpersonal influence between young male adults and young female adults in their purchase decision making process. As young female adults were found to experience a stronger application of interpersonal influence when making their purchase decision compared to the young male adults, a stronger emphasis on marketing strategies relating to social influences should be placed on female products. Nevertheless, a greater emphasis should be placed on the encouragement of female participants based on the results obtained.

The findings from the graphical representation of the moderating effect of gender between informational influence and purchase decision suggests that for both young male and female adults, the informational influence will only have an impact on the vulnerability to the influence in the purchase decision making process when it ranges from moderate to high, below which the informational influence will not be able to influence the susceptibility to the influence in the purchase decision making process. Nevertheless, as noted earlier, for 
the strength of informational influence, susceptibility to the influence in the purchase decision making process is increasing trend at a growing rate for young male adults whereas for young female adults, an increasing at a declining rate was projected. Thus, the findings suggested that there is a dissimilarity in the strength of interpersonal influence in the purchase decision making process between genders young male adults are found to be more susceptible to informational influence than young female adults.

While the findings from the graphical representation of the moderating effect of gender between brand consciousness and purchase decision suggested that for both young male and female adults, the brand consciousness influence will have an impact on the vulnerability to the influence in the purchase decision making process in the of range low to high. Nevertheless, the differences in the strength of brand consciousness resulting in the variation of susceptibility to the influence in the purchase decision making process for both young male and female adults suggested that there is a dissimilarity in the strength of interpersonal influence in the purchase decision making process between genders.

Yet, a more precise indication to capture the distinct opportunities resulting from the variation of strength in both informational and brand consciousness influences between genders in the purchase decision was projected from the study. In order to benefit from young male adults susceptibility to informational influences, strategies that can promote moderate to high informational influences among young male adults seems to be most appropriate. Nonetheless, although returns from strategies promoting moderate to high informational influences may create an opportunity for sales increment, the increase would only be at a declining rate. Whereas, for young female adults, strategies that can promote low to moderate informational influences would be recommended as there will be potentialities to garner a better return-on-investment from product sales. Contrastingly, to gain a comparative advantage from young male adults' susceptibility to brand consciousness influences, strategies that can promote low to moderate brand consciousness influences among young male adults would be highly recommended as the study suggested that this amount of influence would have the highest influence in their purchase decision. Any strategies to promote moderate to high brand consciousness among young male adults should be particularly avoided as these levels of influence would have a declining influence on their purchase decision. Whereas, for young female adults, 
strategies that can promote moderate to high brand consciousness influence among young female adults should be adopted. However, strategies to promote low to moderate brand consciousness influence among young female adults should be not be considered since this amount of influence was found to have a declining influence in the process decision.

\section{Limitations}

Although the main objectives of the study were generally met, some weaknesses still exist. The present exploratory research was limited to a sample of young adults in Klang Valley. Individuals in the Klang Valley were deem to have provided a representation of all young adults throughout Malaysia. As cultures evolve over time, young adults who migrated from home states to Klang Valley might not fully represent the actual behaviour of those in their home states. This is because their residence in the Klang Valley over a long period of time might have caused them to adapt behaviours similar to the ones of the local people.

Furthermore, respondents' exposure to the interpersonal influences may be questioned. In the current study, the degree to which the respondents' exposure to the interpersonal factors influenced their responses is unknown. According to Olson and Thjomoe (2003), it was found that an increase in ones' exposure to a particular subject may make one more vulnerable toward that subject. Relationally, the exposure of young adults to interpersonal factors might influence the potentialities and the level of strength of young adults being vulnerable to the interpersonal factors and ultimately, shaping their final purchasing choice. However, this area of knowledge was not examined in this study, and thus empirical research is required to confirm this.

\section{Future Research Directions}

The present study successfully met its objectives in determining how value expressive, utilitarian, informational, and brand consciousness influences impacts upon young adults' purchase decision making process, and the role of gender in relation to young adults' susceptibility to interpersonal influence in the former process. However, the surface of several limitations and the potential growth of the revitalised area of study may create new avenues for future research to take place. 
An avenue prompting for future research is to include respondents within large formats across states and nations. As respondents were only selected from Klang Valley, the consumer behaviour of individuals residing outside Klang Valley is unknown. In turn, obtaining responses from individuals who reside in other areas would provide a more generalisable result.

Future research could also examine additional product categories to further investigate the vulnerability of young adults to interpersonal influence in their purchase decision making process. In turn, this could further validate the current findings of the study and contribute to the body of knowledge.

Research to further explore the susceptibility model in relation to young adults' exposure to interpersonal influence could also provide interesting and actionable insights for the development of marketing strategies to capture marketing opportunities from the various level of exposed consumers.

\section{References}

Abrams, D. (1994). Social self-regulation. Personality and Social Psychology Bulletin, 5(20), 473-483.

Ariely, D., \& Levav, J. (2000). Sequential choice in group settings: Taking the road less traveled and less enjoyed. Journal of Consumer Research, 27(3), 279-290.

Barber, N., Dodd, T., \& Kolyesnikova, N. (2009). Gender differences in information search: Implications for retailing. Journal of Consumer Marketing, 26(6), 415-426.

Bearden, W. O., \& Etzel, M. J. (1982). Reference group influence on product and brand purchase decisions. Journal of Consumer Research, 11(9), 183-194.

Bearden, W. O., Netemeyer, R. G., \& Teal, J. E. (1989). Measurement of consumer susceptibility to interpersonal influence. Journal of Consumer Research, 1(15), 473-481.

Bertrandias, L., \& Goldsmith, R. E. (2006). Some psychological motivations for fashion opinion leadership and fashion opinion seeking. Journal of Fashion Marketing and Management, 1(10), 2540.

Brinberg, D., \& Plimpton, L. (1986). Self-monitoring and product conspicuousness on reference group influence. Advances in Consumer Research, 1(13), 297-300. 
Brown, J. J., \& Reingen, P. H. (1987). Social ties and word-of-mouth referral behaviour. Journal of Consumer Research, 12(2), 350-62.

Burnkrant, R. E., \& Cousineau, A. (1975). Informational and normative social influence in buyer behaviour. Journal of Consumer Research, 12(2), 206-215.

Chan, K. (2006). Young consumers and perception of brands in Hong Kong: A qualitative study. Journal of Product and Brand Management, 7(15), 416-426.

Coley, A., \& Burgess, B. (2003). Gender differences in cognitive and affective impulse buying. Journal of Fashion Marketing and Management, 7(3), 282-295.

Dahl, D. W., Manchanda, R. V., \& Argo, J. J. (2001). Embarrassment in consumer purchase: The roles of social presence and purchase familiarity. Journal of Consumer Research, 12(28), 473-481.

Delong, M., Bao, M., Wu, J., Chao, H., \& Meng, L. (2004). Perception of US branded apparel in Shanghai. Journal of Fashion Marketing and Management, 2(8), 141-153.

Dodd, C. A., Clarke, I., Baron, S., \& Houston, V. (2000). Looking the part: Identity, meaning and culture in clothing purchasing Theoretical considerations. Journal of Fashion Marketing and Management, 1(4), 41-48.

DSN Retailing Today (2004). Generation Y spending on the rise. DSN Retailing Today, 43(9), 39.

Euromonitor. (2009). Clothing and footwear. Retrieved from Business Source Premier database.

Fournier, S. (1998). Consumers and their brands: Developing relationship theory in consumer research. Journal of Consumer Research, 2(24), 343-373.

Goldsmith, R. E., \& Clark R. A. (2008). An analysis of factors affecting fashion opinion leadership and fashion opinion seeking. Journal of Fashion Marketing and Management, 3(12), 308-322.

Gronhoj, A. (2007). The consumer competence of young adults: A study of newly formed households. Qualitative Market Research: An International Journal, 3(10), 243-264.

Hansen, T., \& Jensen, J. M. (2009). Shopping orientation and online clothing purchases: The role of gender and purchase situation. European Journal of Marketing, 43(9/10), 1154-1170.

Husic, M., \& Cicic, M. (2009). Luxury consumption factors. Journal of Fashion Marketing and Management, 13(2), 231-245.

Keaveney, S. M. (1995). Customer switching behaviour in service industries: An exploratory study. Journal of Marketing, 4(59), 71-82.

160 IJMS 17 (2), 143-164 (2010) 
Kellery, M., \& Kalmus, V. (2009). What makes me cool? Estonian tweens' interpretative repertoires. Young Consumers: Insight and Ideas for Responsible Marketers, 10(4), 329-341.

Kelman, H. C. (1961). Process of opinion change. Public Opinion Quarterly, 24(Spring), 57-78.

Lascu, D. N., Bearden, W. O., \& Rose, R. L. (1995). Norm extremity and interpersonal influences on consumer conformity. Journal of Business Research, 3(32), 201-212.

Livette, M. (2006). The importance of tenure to retirement housing purchasers and the impact of culture upon their attitudes to tenure. Property Management, 5(24), 464-478.

Michaelidou, N., \& Dibb, S. (2009). Brand switching in clothing: The role of variety-seeking drive and product category-level characteristics. International Journal of Consumer Studies, 33, 322-326

Netemeyer, R. G., Bearden, W. O., \& Teel, J. E. (1992). Consumer susceptibility to interpersonal influence and attributional sensitivity. Journal of Psychology and Marketing, 5(9), 379-394.

O'Cass, A., \& Frost, H. (2002). Status brands: Examining the effects of non-product-related brand associations on status and conspicuous consumption. Journal of Product and Brand Management, 11(2), 67-68.

Olson, E., \& Thjomoe, H.M. (2003). The effects of peripheral exposure to information on brand preference. European Journal of Marketing, 37(1/2), 243-255.

Park, C. W., \& Lessig, P. V. (1977). Students and housewives: Differences is susceptibility to reference group influence. Journal of Consumer Research, 4(September), 102-110.

Peter, P. J., \& Olson, J. C. (1996). Consumer behaviour and marketing strategy. London: Irwin.

Phau, I., \& Cheong, E. (2009). Young consumers' evaluations of diffusion brands. Young Consumers, 10(3), 210-224.

Porter, S. S., \& Claycomb, C. (1997). The influence of brand recognition on retail store image. Journal of Product and Brand Management, 6(6), 373-387.

Ratner, R. K., \& Khan, B. E. (2002). The impact of private versus public consumption on variety seeking behaviour. Journal of Consumer Research, 11(29), 246-257.

Rojsek, I. (2001). A comparison of the purchasing and consumption behaviour of Slovenia and other Eastern European consumers. International Marketing Review, 5(18), 509-520.

Schroeder, J. E. (1996). An analysis of the consumer susceptibility to interpersonal influence scale. Journal of Social Behaviour and Personality, 3(11), 585-599. 
Shim, S., \& Gehrt, K.C. (1996). Hispanic and native American adolescents: An exploratory study of their approach to shopping. Journal of Retailing, 3(72), 307-324.

Spero, I., \& Stone, M. (2004). Agents of change: How young consumers are changing the world of marketing. Qualitative Market Research: An International Journal, 2(7), 153-159.

Terry, De J., \& Hogg, M. A. (1996). Group norms and the attitudebehaviour relationship: A role for group identification. Personality and Social Psychology Bulletin, 8(22), 776-793.

Wood, M. (1998). Socio-economic status, delay of gratification, and impulse buying. Journal of Economic Psychology, 1(19), 295-320.

$\mathrm{Xu}, \mathrm{Y}$. (2008). The influence of public self-consciousness and materialism on young consumers' compulsive buying. Young Consumers: Insights and Ideas for Responsible Marketers, 1(9), 3748. 


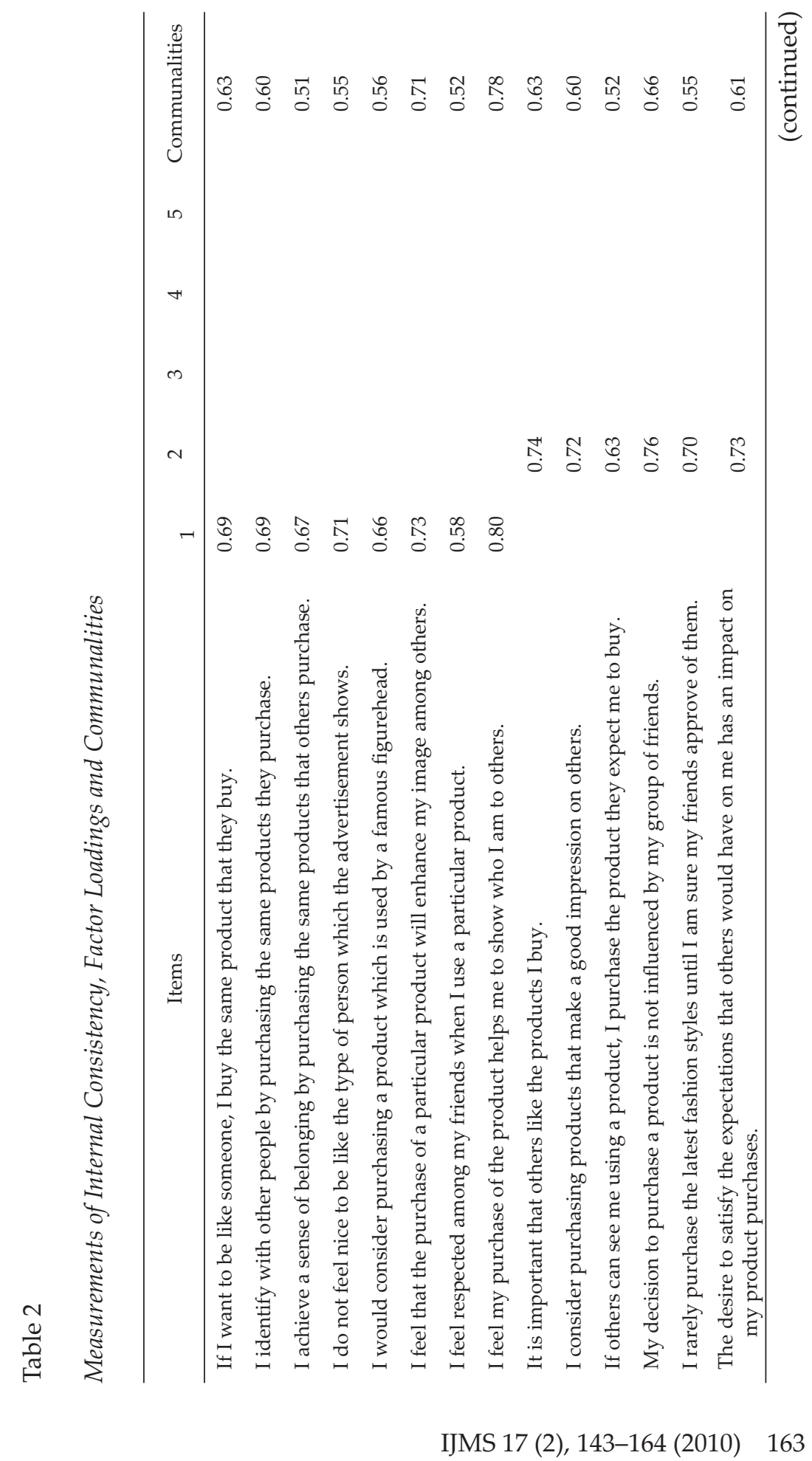




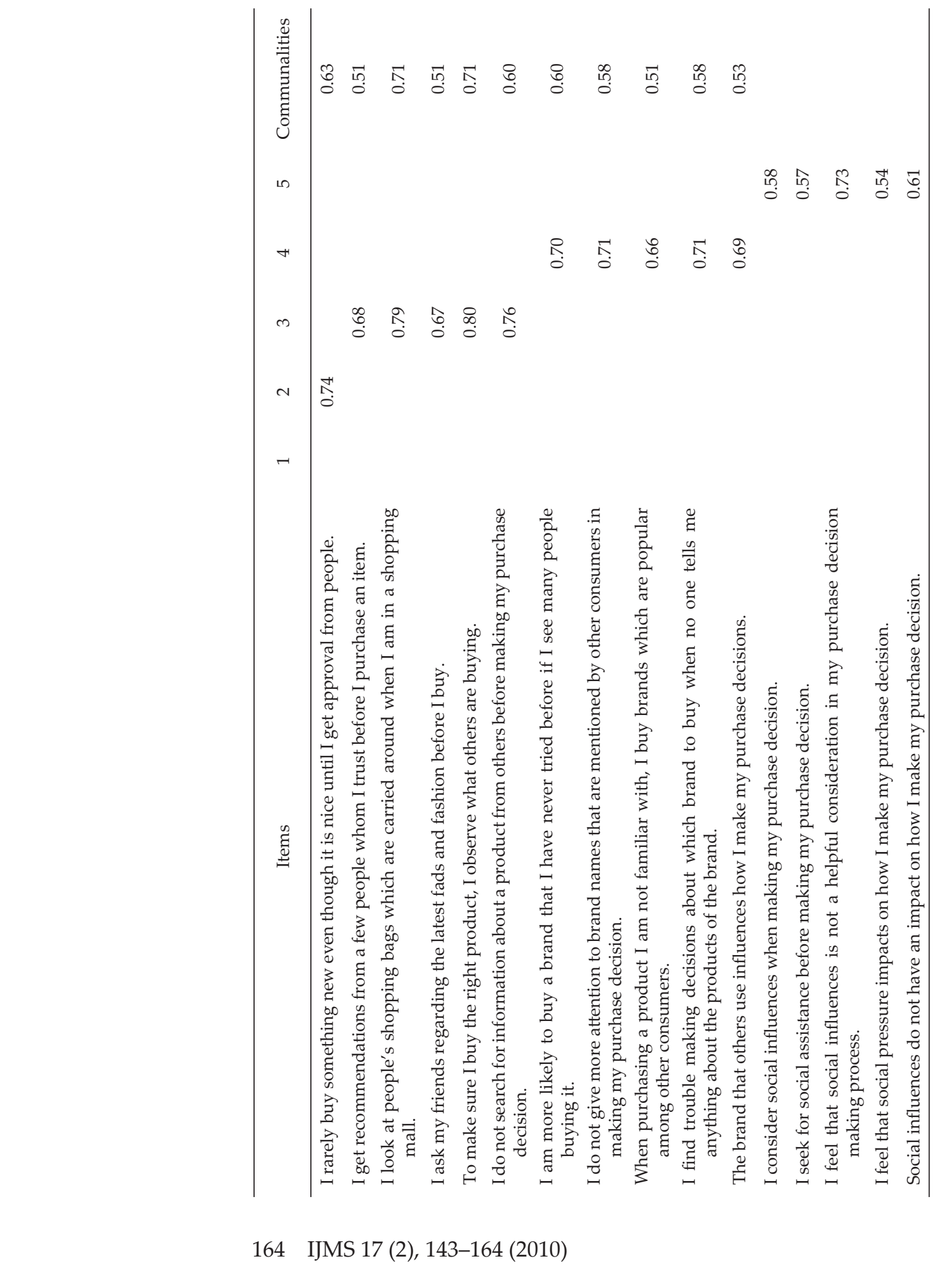

